\title{
SERUM LIPID PROFILE OF SPAYED AND NON-SPAYED FEMALE DOGS ASSOCIATED WITH THE BODY CONDITION SCORE
}

\section{PERFIL LIPÍDICO DE FÊMEAS CANINAS ESTERILIZADAS E NÃO ESTERILIZADAS ASSOCIADO COM O ESCORE DE CONDIÇÃO CORPORAL}

\author{
Patricia Almeida Ferreira ${ }^{1}$ \\ Sabrina de Oliveira Capella ${ }^{1}$ \\ Stephanie de Souza Theodoro² \\ Samuel Rodrigues Felix ${ }^{3}$ \\ William Peres ${ }^{4}$ \\ Márcia de Oliveira Nobre ${ }^{4}$
}

\begin{abstract}
1Pós-graduandas da Universidade Federal de Pelotas, Pelotas, RS, Brasil. - pitiferreira@gmail.com ${ }^{2}$ Graduanda em Medicina Veterinária da Universidade Federal de Pelotas, Pelotas, RS, Brasil.

${ }^{3}$ Professor temporário doutor da Universidade Federal de Pelotas, Pelotas, RS, Brasil.

${ }^{4}$ Professores doutores da Universidade Federal de Pelotas, Pelotas, RS, Brasil.
\end{abstract}

\begin{abstract}
Neutering females may be associated to weight gain in dogs. In order to diagnose possible alterations, such as diabetes and hyperlipidemias, laboratory assessment of carbohydrate and lipid metabolism is important. The aim of this study was to verify glycemia and serum lipid profile in non-spayed and spayed female dogs, and associate these results with the body condition score. Thirty-two spayed $(\mathrm{n}=16)$ and non-spayed $(\mathrm{n}=16)$ female dogs had their blood collected for biochemical analysis, and were classified as to their body condition score (BCS). Nine had normal BCS, 10 were overweight, and 13 were obese. Little difference was observed among spayed and non-spayed dogs. Glycemia of spayed canine females is higher than that of non-spayed dogs, regardless of the body condition score. Likewise, total cholesterol levels are higher in non-spayed females. The HDL is higher in non-spayed obese dogs than in spayed dogs with the same body condition, this parameter did not differ in other weight groups. Contrary to what happens in post-menopausal women, spaying dogs does not seem to have such a strong effect on the metabolic parameters assessed. This study revealed unique results, where neither spaying nor weight group had a strong association with metabolic alterations.
\end{abstract}

Keywords: cholesterol; glucose; spaying.

\section{Resumo}

A esterilização pode estar associada ao ganho de peso em cães. Para diagnosticar possíveis alterações, como diabetes e hiperlipidemias, análises laboratoriais do metabolismo de carboidratos e lipídios são importantes. O objetivo deste estudo foi verificar a glicemia e o metabolismo lipídico em fêmeas caninas não esterilizadas e esterilizadas e associar estes resultados com o escore de condição corporal. Trinta e duas fêmeas caninas, esterilizadas $(n=16)$ e não esterilizadas $(n=16)$ foram submetidas à 
coleta sanguínea para análises bioquímicas e foram classificadas conforme escore de condição corporal (ECC). Nove tiveram ECC normal, 10 apresentavam sobrepeso e 13 eram obesas. Pequenas diferenças foram observadas entre os cães esterilizados e não esterilizados. A glicemia de fêmeas não esterilizadas foi mais elevada em todos os escores corporais, bem como o HDL. Triglicérides, LDL e VLDL foram mais baixos em fêmeas não esterilizadas com sobrepeso quando comparado com animais esterilizados na mesma condição corporal, o que não foi observado em outros grupos. Contrariamente ao que acontece em mulheres após a menopausa, a esterilização em fêmeas de cães não parece ter fortes efeitos sobre os parâmetros metabólicos avaliados. Este estudo apresenta resultados únicos, nos quais nem a esterilização nem o peso possuem forte associação com alterações metabólicas.

Palavras-chave: colesterol; esterilização; glicose.

Recebido em: 04 setembro 2013.

Aceito em 27 janeiro 2015.

\section{Introduction}

A decrease in ovarian hormones during normal estrus cycles is associated with lipoprotein alterations in dogs. An increase in blood cholesterol is observed during the metaestrus, with high levels of lowdensity lipoproteins (LDL) and lower levels of high-density lipoproteins (HDL) observed during the pro-estrus ${ }^{(1)}$. Likewise, post-menopausal women will suffer metabolic alterations in response to the decreasing hormone levels, especially a fall in HDL levels and an increase in total cholesterol and LDL, elevating the risk of coronary diseases ${ }^{(2)}$. Lipoprotein alterations may trigger dyslipidemia, frequently associated with an increase of fat body mass and obesity. A condition of global occurrence, it affects $25 \%$ to $40 \%$ of all dogs and cats, and these overweight pets will, in turn, be at a higher risk of developing other diseases ${ }^{(3)}$.

In humans, metabolic parameters and their relation with hormone levels and body condition has been thoroughly described, as well as the diseases associated with these markers. In dogs, on the other hand, few studies have addressed these questions. In this light, this study assessed blood glucose and serum lipid profile in spayed and non-spayed female dogs with different body condition score (BCS).

\section{Material and Methods}

All animal procedures were approved by the animal experimentation ethics committee of the Universidade Federal de Pelotas - UFPel (CEEA 5271), and all the animals were clinically evaluated by a veterinary. This study used a convenience sample of 32 breedless female dogs, from two to ten years of age, clinically healthy, and receiving standard dog food. Sixteen of these were spayed dogs, the others were reproductively capable. All animals were privately owned, and all castrated females had been spayed over a year before the start of this study. The animals' BCS was registered according to Edney and Smith ${ }^{(4)}$. The dogs were segregated into BCS groups: GI - ideal; GII - overweight; and GIII - obese.

Blood was harvested from the cephalic vein of each dog, in one occasion, after a 12-hour fasting 
period. Three milliliters were collected into a tube with clotting agent and separator gel (Labor®) Import, Bunzl plc, São Paulo, SP, Brazil), after which they were centrifuged and the sera separated. The serum was stored in $2 \mathrm{~mL}$ microtubes at $-80{ }^{\circ} \mathrm{C}$ until use. Serum measurements for triglycerides, total cholesterol, and the HDL fraction were determined through commercial kits (Triglicerides Monoreagente K117, Colesterol Monoreagente K083; HDLLE8; Bioclin ${ }^{\circledR}$, Belo Horizonte, MG, Brazil) using a spectrophotometer (BS-200 Mindray® Corporate Headquarters, China; Thermo Plate $\left.{ }^{\circ}\right)$. The LDL fraction was determined by Friedewald's ${ }^{(5)}$ method, and the VLDL through the function triglycerides/5. The residual blood from the syringe, after collection, was used to assess the animal's glycaemia with the aid of a digital glucometer (Accu-Chek Performa, Accu-Chek®, Jaguaré, SP, Brazil), according to the manufacturer's instructions.

Parameters were compared among spayed and non-spayed females in general, and spayed and nonspayed females in the different BCS classifications. Animals in one BCS group were not compared to those in another. All statistical analysis was conducted in the Statistix 9.0 software, Shapiro-Wilk was used to determine normality, normally distributed data was analyzed through ANOVA, and the Tukey test was used to compare groups. Other data were analyzed through Kruskal-Wallis' test. Statistical significance was considered when $\mathrm{P}$ values were under 0.05 .

\section{Results and Discussion}

Comparing spayed and non-spayed females, those that were not spayed had significantly higher glucose and HDL levels (Table 1); all these levels were, however, within the normal range for adult dogs, and agree with several studies that assess feeding and nutrition ${ }^{(6,7)}$.

Table 1: Metabolic parameters of spayed and non-spayed female dogs

\begin{tabular}{ccccccc}
\hline \multirow{2}{*}{ Females } & \multicolumn{5}{c}{ Assessed parameters (mg/dL) } \\
\cline { 2 - 7 } & Glucose & $\begin{array}{c}\text { Total } \\
\text { cholesterol }\end{array}$ & LDL & HDL & Triglyceride & \multirow{2}{*}{ VLDL } \\
\hline Non-Spayed & $74^{\mathrm{A}}$ & 210 & 99 & $93^{\mathrm{A}}$ & 88 & 17 \\
& $(62-93)$ & $(111-314)$ & $(36-197)$ & $( \pm 41.7)$ & $( \pm 51.5)$ & $( \pm 10.3)$ \\
Spayed & $60^{\mathrm{B}}$ & 202 & 107 & $60^{\mathrm{B}}$ & 108 & 21 \\
& $(43-85)$ & $(120-252)$ & $(75-167)$ & $( \pm 19.9)$ & $( \pm 77.3)$ & $( \pm 15.4)$ \\
\hline
\end{tabular}

Values represent mean ( $\pm \mathrm{SD}$ ), or median (Min.-Max.), according to normality.

Different letters indicate difference among groups $(\mathrm{P}<0.05)$.

Castration has been shown to significantly increase weight gain in female dogs fed ad libitum ${ }^{(8)}$. However, this is minimized if they are fed a controlled diet and exercise regularly ${ }^{(9)}$. A decrease in estrogen and an increase in androgen are responsible for post-menopausal alterations in glucose homeostasis in genetically predisposed women ${ }^{(10,11,12)}$ and dogs may suffer similar alterations.

Blood HDL levels described here were similar to those found by Jeusette et al. ${ }^{(13)}$, who assessed healthy dogs. Lower levels have been described in healthy, eutrophic $(42.12 \mathrm{mg} / \mathrm{dL})$ and obese $(62.46$ $\mathrm{mg} / \mathrm{dL}) \operatorname{dogs}{ }^{(14)}$; however, these were also within normal limits. Lower HDL levels in spayed, compared to non-spayed, females has been described ${ }^{(15)}$ with a 1.87 times decrease one year after spaying. The results described here also mirror the lipoprotein patterns seen in post-menopausal women, who show a progressive decrease in $\mathrm{HDL}^{(16,17,18)}$. This is because estrogen will suppress the 
activity of hepatic lipase, the enzyme which degrades $\mathrm{HDL}^{(19)}$.

Regarding the BCS, nine animals had an ideal BCS (GI), 10 were considered overweight (GII), and 13 were obese (GIII). No statistically significant difference was shown in glucose, LDL, HDL, VLDL, and triglyceride levels among weight groups (Table 2).

Table 2: Blood glucose, triglyceride and cholesterol levels in ideal, overweight and obese, spayed and non-spayed female dogs

\begin{tabular}{|c|c|c|c|c|c|c|c|}
\hline \multicolumn{8}{|c|}{ Assessed Parameters (mg/dL) } \\
\hline & & Glucose & Total Cholesterol & LDL & HDL & Triglycerides & VLDL \\
\hline \multirow{4}{*}{ GI } & NS & 76 & 220 & 148 & 70 & 91 & 18 \\
\hline & $\mathrm{n}=5$ & $( \pm 4.8)$ & $(130-310)$ & $(60-197)$ & $( \pm 38.53)$ & $(61-217)$ & $(12-43)$ \\
\hline & S & 63 & 214 & 128 & 64 & 120 & 24 \\
\hline & $\mathrm{n}=4$ & $( \pm 14.3)$ & $(198-252)$ & $(100-167)$ & $( \pm 14.38)$ & $(71-160)$ & $(14-32)$ \\
\hline \multirow{4}{*}{ GII } & NS & 78 & 184 & 55 & 136 & 50 & 10 \\
\hline & $\mathrm{n}=5$ & $(65-86)$ & $(111-314)$ & $(36-127)$ & $(67-171)$ & $(35-81)$ & $(7-16)$ \\
\hline & S & 66 & 168 & 112 & 36 & 60 & 12 \\
\hline & $\mathrm{n}=5$ & $(54-82)$ & $(120-208)$ & $(75-116)$ & $(24-82)$ & $(34-77)$ & $(6-15)$ \\
\hline \multirow{4}{*}{ GIII } & NS & 66 & 210 & 115 & $81^{\mathrm{A}}$ & 95 & 19 \\
\hline & $\mathrm{n}=6$ & $(62-93)$ & $(195-267)$ & $(82-142)$ & $(69-131)$ & $( \pm 55.5)$ & $( \pm 11.1)$ \\
\hline & $\mathrm{S}$ & 60 & 203 & 96 & $67^{\mathrm{B}}$ & 138 & 27 \\
\hline & $\mathrm{n}=7$ & $(43-85)$ & $(140-215)$ & $(82-132)$ & $(42-83)$ & $( \pm 104.7)$ & $( \pm 20.9)$ \\
\hline
\end{tabular}

BCS: Body condition score group; GI: Ideal, GII: Overweight, GIII: Obese.

NS: Non-spayed, S: Spayed.

Values represent mean $( \pm \mathrm{SD})$, or median (Min.-Max.), according to normality.

The behavior of cholesterol parameters did not differ among weight classes, contrary to what is usually observed in humans ${ }^{(20)}$ and, occasionally, in $\operatorname{dog} s^{(13,21)}$. On the other hand, our results seem to corroborate what is usually found in this species ${ }^{(22,15)}$. Likewise, cholesterol values did not vary among spayed and non-spayed dogs, contrary to the observed effects of menopause in women ${ }^{(2)}$.

Regarding lipoprotein fractions, LDL was higher in spayed ideal and overweight dogs than in nonspayed dogs in the same weight groups. This result is expected, since one of the effects of estrogen is keeping LDL at normal levels ${ }^{(23)}$. The overall results were within normal limits, and similar to what has been described fro dogs ${ }^{(15)}$ and post-menopausal women ${ }^{(24)}$. Barrie et al. ${ }^{(14)}$ found markedly lower LDL values in normal and obese dogs (30.96 mg/dL and $33.84 \mathrm{mg} / \mathrm{dL}$, respectively); however, they were assessing dogs suffering from diabetes, hyperadrenocorticism and hypothyroidism.

Triglyceride levels were lower in non-spayed females in all BCS groups; however, no statistically significant difference was observed. These results corroborate what has been described in similar situations ${ }^{(15)}$. Our results were considerably higher than those described by Brunetto et al. ${ }^{(21)}$, who found $89.3 \mathrm{mg} / \mathrm{dL}$ and $56.4 \mathrm{mg} / \mathrm{dL}$ of triglycerides for obese and normal dogs, respectively. Likewise, Chikamune et al. ${ }^{(22)}$ found lower levels of triglycerides in normal dogs $(35 \mathrm{mg} / \mathrm{dL})$, but comparable levels in obese dogs $(100 \mathrm{mg} / \mathrm{dL})$.

Contrary to what has been described, particularly for humans, where women usually develop glycemic and lipid alterations after menopause, the spayed dogs assessed in this study did not have the clear alteration that would be expected. Although feeding is often associated with dyslipidemia, and hormone levels affect carbohydrate and lipid metabolism, both in humans and dogs, weight disparities and spaying did not seem to have much of an effect on these parameters in this study. 


\section{Conclusion}

Glycemia of spayed canine females is higher than that of non-spayed dogs, independent of the body condition score. Likewise, total cholesterol levels are higher in non-spayed females. The HDL is higher in non-spayed obese dogs than in spayed dogs with the same body condition, this parameter did not differ in other weight groups.

\section{Acknowledgments}

Financial support and scholarships were funded by CAPES/FAPERGS and CNPq (CNPq: 305072/2012-9). The authors thank Laboratório Dr. Rouget Perez for their technical support.

\section{References}

1. Downs LG, Wills JM, Zani V, Crispin SM, Bolton CH. Changes in plasma lipoprotein during the oestrus cycle of the bitch. Research in Veterinary Science. 1994;56(1):82-88.

2. Stevenson JC, Crook D, Godsland IF. Influence of age and menopause on serum lipids and lipoproteins in healthy women. Atherosclerosis. 1993;98(1):83-90.

3. German AJ. The growing problem of obesity in dogs and cats. The Journal of Nutrition. 2006;136(suppl.):1940S-6S.

4. Edney ATB, Smith PM. Study of obesity in dogs visiting veterinary practices in the United Kingdon. Veterinary Record. 1986;118(14):391-396.

5. Friedewald WT, Levy RI, Fredrickson DS. Estimation of the Concentration of Low-Density Lipoprotein Cholesterol in Plasma, Without Use of the Preparative Ultracentrifuge. Clinical Chemistry. 1972;18(6):499502.

6.Diez M, Michaux C, Jeusette I, Baldwin P, Istasse L, Biourge V. Evolution of blood parameters during weight loss in experimental obese Beagle dogs. Journal of Animal Physiology and Animal Nutrition. 2004;88(3-4):166-71.

7. Nascimento MA, Conti RMC. Verificação da curva glicêmica em cães não diabéticos com diferentes tipos de alimentação. Anuário da produção de iniciação científica discente. 2008;11(12):239-252.

8. Houpt KA, Coren B, Hintz HF, Hilderbrant JE. Effects of sex and reproductive status on sucrose preference, food intake and body weight of dogs. Journal of the American Veterinary Medical Association. 1979;15(174):1083-1085.

9. Leroux PH. Thyroid status, oestradiol level, work performance and body mass of ovariectomised bitches and bitches ovarian autotransplants in the stomach wall. Journal of the South African Veterinary Association. 1983;54(2):115-117.

10. Haffner SM, Katz MS, Stern MP, Dunn JF. The relationship of sex hormones of hyperinsulinemia and hyperglycemia. Metabolism. 1988;37(7):683-688.

11. Haffner SM, Valdez RA, Morales PA, Hazuda HP, Stern MP. Decreased sex hormone-binding globulin predicts noninsulin-dependent diabetes mellitus in women but not in men. The Journal of Clinical 
Endocrinology \& Metabolism. 1993;77(1):56-60.

12. Wilson PWE. Does estrogen reduce glycemic levels? Diabetes Care. 1998;21(10):1585-1586.

13. Jeusette IC, Lhoest ET, Istasse LP, Diez MO. Influence of obesity on plasma lipid and lipoprotein concentrations in dogs. American Journal of Veterinary Research. 2005;66(1):81-86.

14. Barrie J, Watson TDG, Stear MJ, Nash AS. Plasma cholesterol and lipoprotein concentrations in the dog: The effects of age, breed, gender and endocrine disease. Journal of Small Animal Practice. 1993;34(10):507512.

15. Schimdt C, Lopes MD, Silva MC, Fighera RA, Souza TM. Perfil lipoprotéico de cadelas submetidas à ovário-histerectomia com e sem reposição hormonal. Arquivo Brasileiro de Medicina Veterinária e Zootecnia. 2004;56(4):49-456.

16. Wolfe BM, Huff MW. Effects of continuous low-dosage hormonal replacement therapy on lipoprotein metabolism in postmenopausal women. Metabolism. 1995;44(3):410-417.

17. Speroff L, Rowan J, Symons J, Genant H, Wilborn W. The comparative effect on bone density, endometrium, and lipids of continuous hormones as replacement therapy. (CHART study). A randomized controlled trial. Journal of American Medical Association. 1996;276(17):1397-1403.

18. Sullivan JM. Estrogen replacement therapy. American Journal of Medicine. 1996;101(4suppl 1):56S-60S.

19. Tikkanen MJ, Nikkila EA. Regulation of hepatic lipase and serum lipoproteins by sex steroids. American Heart Journal. 1987;113(2):562-567.

20. Vasudevan M, Tchoua U, Gillard BK, Jones PH, Ballantyne CM, Pownall HJ. Modest diet-induced weight loss reduces macrophage cholesterol efflux to plasma of patients with metabolic syndrome. Journal of Clinical Lipidology. 2013;7(6):661-70.

21. Brunetto MA, Nogueira S, Sá FC, Peixoto M, Vasconcellos RS, Ferraudo AJ, Carciofi AC. Correspondência entre obesidade e hiperlipidemia em cães. Ciência Rural. 2011;41(2):266-271.

22. Chikamune T, Katamoto H, Ohashi F, Shimada Y. Serum Lipid and Lipoprotein Concentrations in Obese Dogs. Journal of Veterinary Medicinal Science. 1995;57(4):595-598.

23. Castañeda GB, Pachón JAP. Efecto de la terapia estrogenica y combinada estrogeno-progestacional sobre el perfil lipídico em pacientes com suplencia para sindrome climaterico; Revista Colombiana de Menopausia, $2001 ; 5(1)$

[Fonte: $<$ http://www.encolombia.com/medicina/revistasmedicas/menopausia/vol5199/efectos_meno5-1>]. Espanhol.

24. Bansal S, Buring JE, Rifai N, Mora S, Sacks FM, Ridker PM. Fasting Compared With Nonfasting Triglycerides and Risk of Cardiovascular Events in Women. The Journal of the American Medical Association. 2007;298(3):309-316. 